\title{
Electricity generation from renewables in Madagascar : opportunities and projections
}

Jean Philippe Praene ${ }^{\mathrm{a}, *}$, Mamy Harimisa Radanielina ${ }^{\mathrm{b}}$, Vanessa Rolande Rakotoson ${ }^{\mathrm{a}}$, Ando Ludovic Andriamamonjyc ${ }^{c}$ Frantz Sinama ${ }^{a}$, Dominique Morau ${ }^{\mathrm{a}}$, Hery Tiana Rakotondramiarana ${ }^{\mathrm{b}}$

${ }^{a}$ Laboratory of Physics and Mathematical Engineering for the study of Energy, Environment and Building,117 rue du General Ailleret - P.O. Box 97430 Le Tampon - Reunion, France

${ }^{b}$ Institute for the Management of Energy (IME) - University of Antananarivo, P.O. Box 566, Antananarivo 101, Madagascar

${ }^{c}$ Department of Civil Engineering, Building Physics Section, KU Leuven, Kasteelpark Arenberg 40 - P.O. Box 02447, BE-3001 Heverlee, Belgium

\begin{abstract}
Climate change is the greatest challenge of our time for development. Adaptation to this change combined with the reduction of greenhouse gas emissions can help to boost the economic transformation which stimulates growth, fills the energy gap and reduces poverty. This paper focuses on the potential of renewable energy sources (RES) for electricity generation in Madagascar which is a lower-income country. A large accessibility to electricity could be a driving force for the economic development of this fourth worldwide Island. The Electricity mix is currently heavily dependent to fossil fuel imports. Indeed, most of the electric demands are fulfilled by diesel power plants.An overview of the power situation and renewable energy potential of Madagascar is first presented, then different scenarios for the evolution its electricity mix are proposed.
\end{abstract}

Keywords: Renewable Energy, Life Cycle Analysis, Madagascar, Island

\section{Contents}

1 Introduction

$2 \quad$ Energy policy

2.1 Political strategies of energy sector development

2.2 Energy policy background .

2.3 Research development policy . . . . . . . . . . . . . . . . . . . . . . . . . . . 7

3 Renewable energy sources

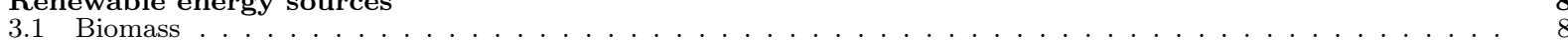

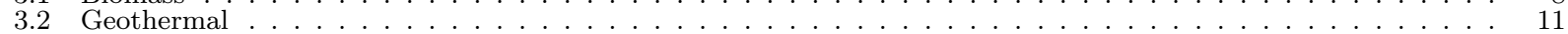

3.3 Hydropower . . . . . . . . . . . . . . . . . . . . . . . . . . . . . . . . . . . 12

3.3 Development status . . . . . . . . . . . . . . . . . . . . . . . . . . . . . .

3.3 .2 Hydropower policy . . . . . . . . . . . . . . . . . . . . . . . . . . . . . . . . . . . . . . . .

*Corresponding author, Tel. +262 692235566

Email address: praene@univ-reunion.fr (Jean Philippe Praene)

$U R L$ : piment.univ-reunion.fr (Jean Philippe Praene) 


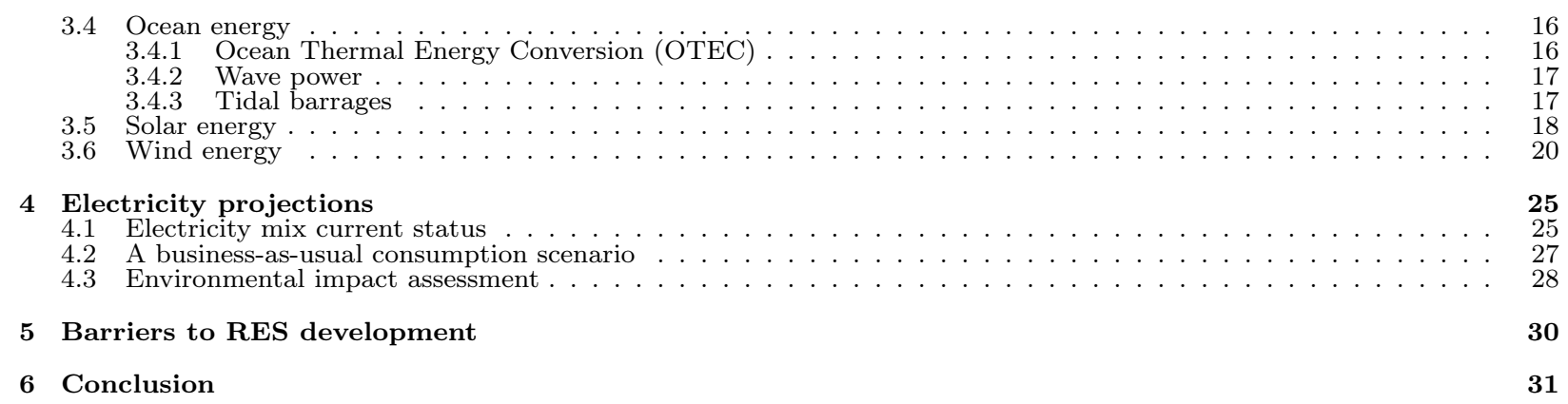

\section{Introduction}

In the last two decades, the climate change mitigation has been more and more considered by national energy policy. Many papers discusses the form of energy production and its evolution, [1-3]. Most of papers highlighted the deployment of renewable energy systems for electricity in order 5 to limit the dependence to fossil fuels, [4-8]. While the world energy needs grew by around $45 \%$ during the last decade [9], the availability of electricity, qualified as a noble energy, is critical for economic development especially for developing countries in sub-Saharan Africa countries such as Madagascar. However, energy consumption per inhabitant remains one of the lowest in the world, around 0.315 toe/year in this area [10], as the world average is around 1.6 toe/year. During the last two years Madagascar is ranked as the 188-th over 189 economies in terms of getting electricity, [11].

In 1999, the Malagasy government introduced a reform of the energy sector, including power, adopting Act No. 98-032 of January 20, 1999 [12], supported by the Decrees No. 2001-803 of September 19, 2001 and No. 2001-849 of September 26, 2001, which respectively establish the organization of

the operation of the $\mathrm{ORE}^{1}$ agency and the conditions power pricing in Madagascar.

Later, Act No. 2002-001 of October 7, 2002 [13], established the creation of the $\mathrm{FNE}^{2}$, followed by the $\mathrm{ADER}^{3}$ by Decree No. 2002-1550 of December 3, 2002. These reforms aims at restructuring the energy sector by developing new operational ways and by turning to other alternative energies, namely renewable energy sources (RES).

\footnotetext{
${ }^{1}$ « Office de Régulation de l'Electricité » or Office of Power Regulation

${ }^{2}$ « Fonds National pour l'Electricité » or National Fund for the Electricity

${ }^{3}$ « Agence de Développement de l'Electrification Rurale» or Agency for the Development of Rural Electrification
} 
According to the energy inventory drawn up by the $\mathrm{MEM}^{4}[14]$ and the study report of the CREAM 5 [15], wood energy has the highest share (92\%) in the total energy supply in Madagascar, followed by fossil fuel $(7 \%)$. Only less than $1 \%$ of this demand is supplied by other renewable energy sources. This high share of wood energy is explained by its accessibility and its low cost for the population. Madagascar has a low rate electricity access due to its high price and the insufficient quantity production. The national rate of electrification is only $4.7 \%$ only. In urban zones, such as Antananarivo, this value could reach up. In view of the geographic and climatic conditions in Madagascar, the reality of development of renewable energy technologies (RETs) is complicated despite numerous research works carried out in this area.

Therefore, this paper aims at reviewing potential of RES in Madagascar and its perspective. The barriers of RES development are highlighted to evaluate the energy situation and to conceive challenges for the future. This analysis has been investigated through the first definition proposed by [16-18]. The discussion on the barriers in Madagascar will highlight the difficulty to turn from words to deeds.

\section{Energy policy}

\subsection{Political strategies of energy sector development}

With regard to the strategic orientation of the energy sector policy in Madagascar, several actions in relation with expected results have been considered to reach the finalities of good governance and economic and social development. Figure 1 shows the energy sector policy organization in Madagascar:

\footnotetext{
${ }^{4}$ « Ministère de l'Energie et des Mines » or Ministry of Energy of Madagascar

${ }^{5}$ « Centre de Recherche, d'Etudes et d'Appui à l'Analyse Economique à Madagascar» or Research Center for study, support and economic analysis in Madagascar
} 
ENERGY SECTOR POLICY IN MADAGASCAR

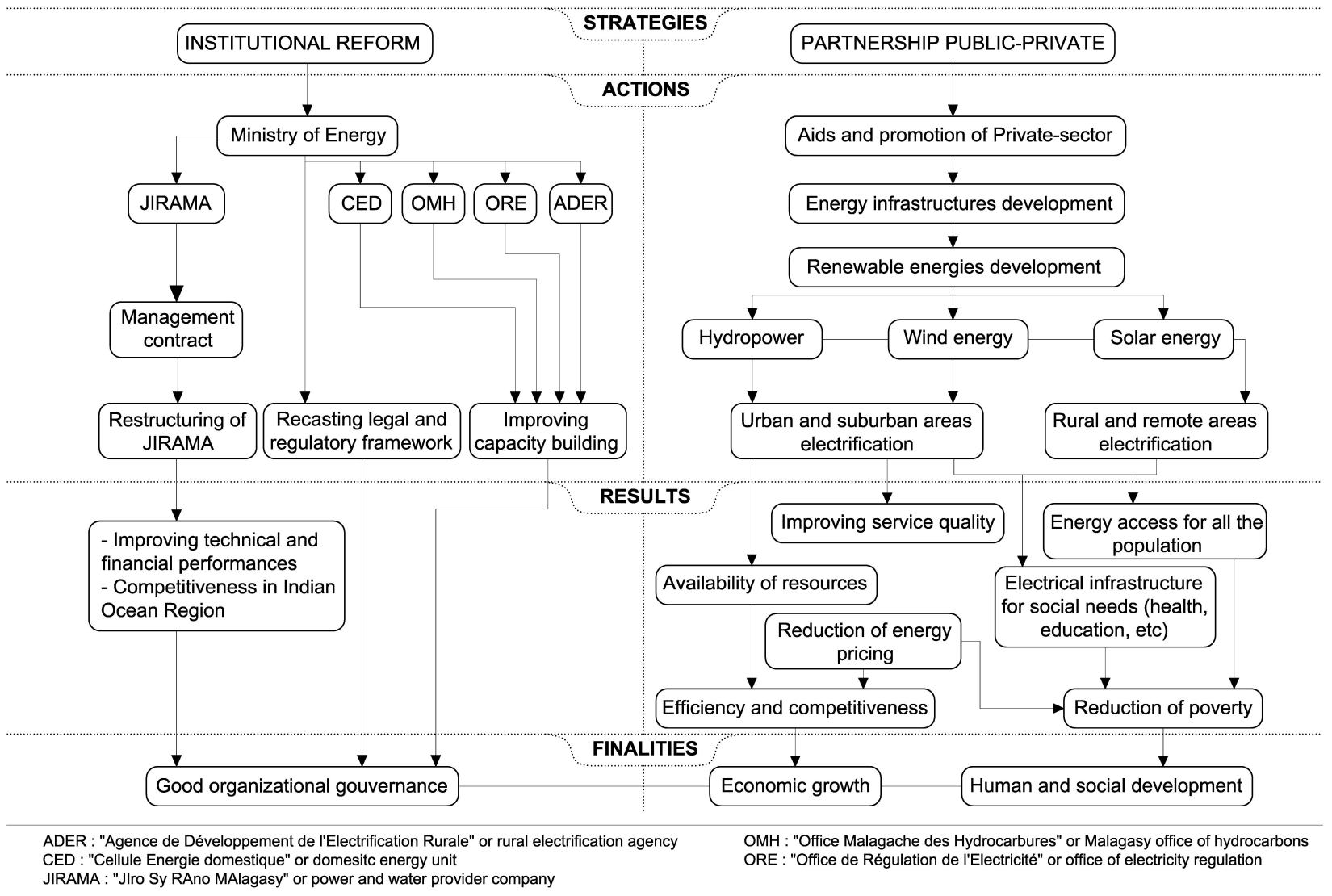

Figure 1: Flowchart of the energy sector policy in Madagascar

As shown in figure 1, the energy sector policy is divided in two main strategies, namely: the institutional reform and public-private partnership. On the one hand, the institutional reform highlights the restructuring of JIRAMA ${ }^{6}$ Company, the recasting legal and regulatory framework and the capacity building of the organizations attached to the Ministry of Energy. On the other hand, the related actions of public-private partnership involve the RES development such as hydropower, solar energy and wind energy for the global electrification both in rural and urban areas.

Thus, the expected results of the energy sector policy tend to improve technical and financial performances for inciting competitiveness especially in Indian Ocean region. These results should be reflected in the service quality mainly in urban areas which mostly suffer from electrical load shedding during peak demand periods. For rural and remote areas, the main result is the energy

\footnotetext{
${ }^{6}$ « Jiro sy Rano Malagasy » or electricity and water provider company
} 
access for social needs especially health and education. These outcomes tend to substantially reduce poverty and contribute to the development of Madagascar.

\subsection{Energy policy background}

Table 1 overviews the main legal acts in the energy sector in Madagascar.

Table 1: Overview of the legal acts in the energy sector in Madagascar

\begin{tabular}{ccc}
\hline Type of act & Reference & Item \\
\hline Act & No. $98-032$ & Reformed the energy sector \\
Act & No $2002-001$ & Referred to the FNE \\
Decree & No 2001-173 & Fixed the conditions and terms of application of the Act No. 98-032 \\
Decree & No 2001-803 & Specified the organization of the operation of the ORE \\
Decree & No 2001-849 & Referred to the conditions of electricity pricing in Madagascar \\
Decree & No 2002-1550 & Instituted the creation of the ADER \\
Decree & No 2003-194 & Amended the decree No 2001-803 \\
Decree & No 2003-510 & Amended the decree No 2002-1550 \\
Ordinance & No $74002-1974$ & Referred to the orientation of water and electricity policy \\
Ordinance & No $6678-2001$ & Referred to permission and statements for self-generation of electricity \\
Ordinance & No $12592-2001$ & Fixed the amounts and terms of instruction fees payment for permission request \\
\hline
\end{tabular}

Source: Official Journal of Madagascar, Ministry of Energy

Before 1975, the Malagasy government applied a state monopoly on the energy sector that was justified by political and economic contexts in those days. Since then, as referred in Table 1, the Ordinance No. 74-002 of February 4, 1974, was acted. This document referred to the orientation of water and power policy of which the clauses solely conferred to JIRAMA Company the exploitation right of the electricity in the country. The main target was progressively to liberalize the production activities according to the new economic policy which aims at lightening the obligation of the public administration in the energy sector.

The legal and regulatory framework has positively evolved during the last decade with the power sector reform. It began in 1998 with the Act No. 98-032 [12] that favoured the private investments and competition in the sector. Indeed, the adoption of the decrees No. 2001-173 and No. 2001-803, pursuant to Act No. 98-032, defining the organization of ORE, has helped the arrival of investors in the power generation.

Besides, in 2002, the FNE and the ADER were created and respectively instituted by the Act No 2002-001 [13] and the decree No. 2002-1550, in order to improve electrification rate of the country 
mainly in rural areas and to develop the renewable energy sources such as wind energy, hydropower and solar energy. Unfortunately, it was only since 2006 that the abovementioned two institutions were completely operational without really satisfying the desired targets by the reform.

In 2009, the price strategies by type of production has been introduced including pricing adjustments in relation to the variation of the economic inputs namely fuel pricing and local currency value (Ariary). Thus, the government would limit structural deficits relating to the electrification of remote areas. Nevertheless, these pricing reforms have not been implemented even though the fuel pricing has regularly increased, since then, in addition to the depreciation of the Ariary.

Lately, in 2013, a survey was carried out by an international firm purposing the restructuring and updating of the organization of JIRAMA Company; first, separating its activities of production, transmission and distribution, and second, changing its legal status into a limited company liable to private law. That study is currently in process and needs the help of the government to make a decision in JIRAMA's management as soon as possible.

Hence, the slow progress in the energy sector for several years in Madagascar was not exclusively related neither to the deficiency of the regulatory framework nor to erroneous strategic priorities, but mainly due to the lack of perseverance and rigour in the implementation of these strategic priorities as well as to the large share of the State in the JIRAMA's management that have clearly handicapped the energy sector development.

With respect power production, since 1975, the JIRAMA Company or the national water and electricity provider, has been in charge of electricity distribution through the whole territory and remains the first power provider in Madagascar. However, due to lack of investment, its ability to provide all the regions is limited, especially the rural areas. To manage this situation, the Malagasy government implemented a new policy developing the partnership between public and private sectors in 1999. As said in section 2.2, to reinforce JIRAMA production, other private partners also contributed into electricity production, by purchasing energy, by renting materials to JIRAMA Company or by donations. These energies are included into the interconnected national network, to satisfy the needs of the customers. Key partners of JIRAMA include:

- the Sherritt International Corporation, through the Ambatovy Project located in Madagascar since 2007;

- the AGGREKO company, renting generation set to JIRAMA Company; 
- the HYDELEC Madagascar company, that carries out studies, builds and operates hydroelectric and thermal power plants since 2007;

- the Henri Fraise Fils \& Cie has at its own disposal hydroelectric power plants installed in independent Power, thermal power plants entering, and several other power plants in rent;

- the EDM company, created in 2005, aims to offer energy solutions in Madagascar;

- the ENELEC company, private energy producer through thermal power plant, located in Madagascar since 2006.

\subsection{Research development policy}

Six main targets have been highlighted to improve the RES research development:

o Target 1: Knowledge of the current situation of the research in the RES field. The main works consist in inventorying the legal and regulatory framework relating to RES and energy research, assessing the potential effects of energy sources (both used and usable ones), and doing an inventory of fixtures of current research guidelines in technical, economic, social, cultural and environmental point of view, in order to produce a reference document for the researchers, partners and policy makers.

o Target 2: Promotion of the innovation in RES research with high added value for Madagascar. It begins with the setting up of technical and scientific research platform by introducing the results of the research in training scheme and reinforcing the renewable energy field in the LMD system of the Malagasy higher education. The second point tends to develop the renewable energy research in terms of the specificity of each region and to motivate the development actors in the project incubation process. The third activity concerns the creation of the funding for the scheme experimentation by activating the feasibility study, ensuring the consistency of the initiatives and prospecting private resources to supply the competitive fund. The last activities tend to establish evaluation criteria in order to measure the innovative and priority schemes efficiency in relation with the productive sectors; and to ensure the recommendation achievement by scheme periodical assessment

o Target 3: Taking part in the achievement of national targets in the green economy field and climate change mitigation. It assumes to inventory and assess the self-induced and planned 
practices for capitalization and valorization, to develop viable and innovative renewable energy models for climate change mitigation and to constitute a preferred area, exchange and work field of researchers and actors for promoting RES.

o Target 4: Strengthening of the capacity building of the main actors in technical, institutional and organizational renewable energies field. It means to reinforce the capacity building of the actors in the management of energy, environment, climate change and water for the synergy between research and development. Indeed, it also implies to develop national or international public-private partnership and to take incentive policies and motivation for research guidelines.

o Target 5: Highlighting of the results of research in RETs for sustainable development. It consists in inventorying the current and potential partners, encouraging the private investments in renewable energy sector by founding fiscal incentive policies, supporting individual investments for operating in RES. Added to that the importance of the electronic media organization diffusing the knowledge in RES. It includes considering information and diffusion strategies that relate the results of the energy research, proposing in Madagascar money-bill the insertion of investment funds for financing the valorization of the RES research results, developing the partnership between the ministry of Research and the energy sector for promoting the RES projects and sustaining the saving of the results of Research in relation with $\mathrm{OMAPI}^{7}$

o Target 6: Ensuring of the effective Research guidelines. It relates the establishment monitoring and evaluation system for coordinating the Research guidelines, and the reinforcement of the regional, national and international networks.

\section{Renewable energy sources}

\subsection{Biomass}

Madagascar is the country that has the greatest amount of biomass per hectare about $114 \mathrm{~m}^{2} / \mathrm{ha}$ among the countries of southern Africa. In 1990, about $18 \%$ of the total area of the country was forested corresponding to 10,746,403 ha [19]. However as shown in figure 2, within a decade, there would be no more than 9,294,237 ha. The decrease of forest area is mainly due to bush fires and

\footnotetext{
${ }^{7}$ « Office MAlagache de la Propriété Intellectuelle » or Malagasy office for industrial property rights
} 
the unsustainable management. The use of wood for agriculture, cooking and building materials has a significant effect on the forest.

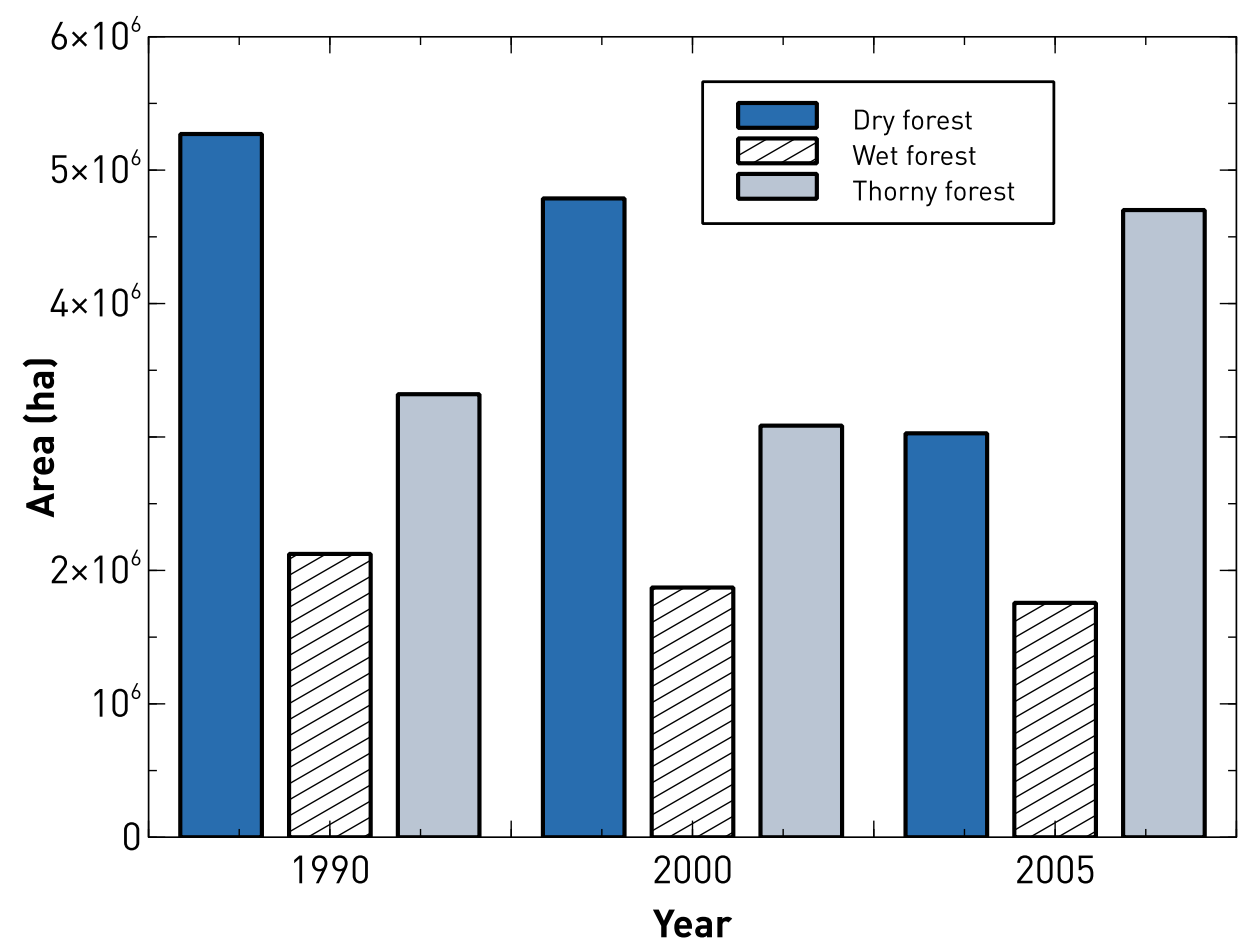

Figure 2: Area of forest cover

According to the USAID ${ }^{8}$ [20], the wood consumption in Madagascar is 21.7 million $\mathrm{m}^{3}$, including 41.8\% from firewood and $39.7 \%$ from charcoal manufacture. The $18.5 \%$ remaining are devoted to wood-processing industries [21]. Table 2 shows the estimation of the average annual wood consumption in Madagascar.

Table 2: Annual wood consumption [20]

\begin{tabular}{lcc}
\hline Type of wood & Average $\left(\right.$ million $\left.\mathrm{m}^{3}\right)$ & Percent $(\%)$ \\
\hline Firewood & 9,026 & 41.8 \\
Charcoal & 8,575 & 39.7 \\
Wood construction and service & 4,006 & 18.5 \\
Total & 21,607 & 100 \\
\hline
\end{tabular}

\footnotetext{
${ }^{8}$ United States Agency for International Development
} 
For wood CIS ${ }^{9}$, the amount of operated logs between 1998 and 2002 was $418,042 \mathrm{~m}^{3}$. On the average, only $35 \%$ of these logs are processed into end-products. $65 \%$ are residues composed by chips, sawdust and wood scraps. Logs chips occupy the major portion of logs compared to the other two, sawdust residues being in low proportion.

- Home cooking : In 2011, 92.64\% of energy production of Madagascar rely on wood energy, against $7.36 \%$ petroleum products and less than $1 \%$ of renewable energies. In areas where there are logging and wood processing plants, residents nearby use residues for cooking and heating.

- Brick cooking : Rapid population growth resulted in an increase in the construction of houses bricks-made mainly based in the Analamanga region. Wood residues are among the three main fuels used with the peat and the rice ball.

- Drying in wood processing industries : In large wood-processing industries, a part of the residues is used for drying of wood through a boiler.

- Mixing with organic fertilizers : Wood residues (leaves, roots, sawdust) especially those left on the site are mixed with the manure as organic fertilizer.

Several projects in Madagascar are funded by the European Union, such as GESFORCOM ${ }^{10}$ project in connection with the Niger and Mali. These projects focused on the development of rural electrification as an efficient way to reduce poverty based on wood sector, waste recovery (rice husk ...). Urban waste management is a crucial point for the major cities of Madagascar. This question both concerns health issue and energy recovery. For instance, the commune of Mahajanga has a yearly production of 30,000 tons of organic waste. Only 30\% is currently land-filled. In 2013 a power plant was set up in Mahajanga to treat 12,000 tons of organic wastes to agriculture compost. The windrow composting allows to avoid up to 150,000 tons of $\mathrm{CO}_{2}$ in 10 years. The project also aims at enhancing as much as possible other types of urban wastes via the production of:

- Interlocking pavers, derived from the recycling of plastics, ubiquitous bags in the urban environment;

- Continuous horns and hooves of zebus, biofertilizers particularly rich in nitrogen (from 11 to 16\%) of assimilable nitrogen);

\footnotetext{
${ }^{9}$ Construction, Implementation and Service

${ }^{10}$ Communal management, management community and Local development
} 
- Fuel Briquettes of the recycling of wood waste and green fuels, replacing charcoal both at the level of households and industrial processes (boilers, dryers,... ).

This model of urban waste management could probably be applied to other main cities of the country.

\subsection{Geothermal}

It is worth noting that geothermal project development cycle for power production can be subdivided into eight successive stages: Preliminary survey, Exploration, Test drilling, Project review and planning, Field Development, Construction, Start-up and commissioning, Operation and Maintenance [22].

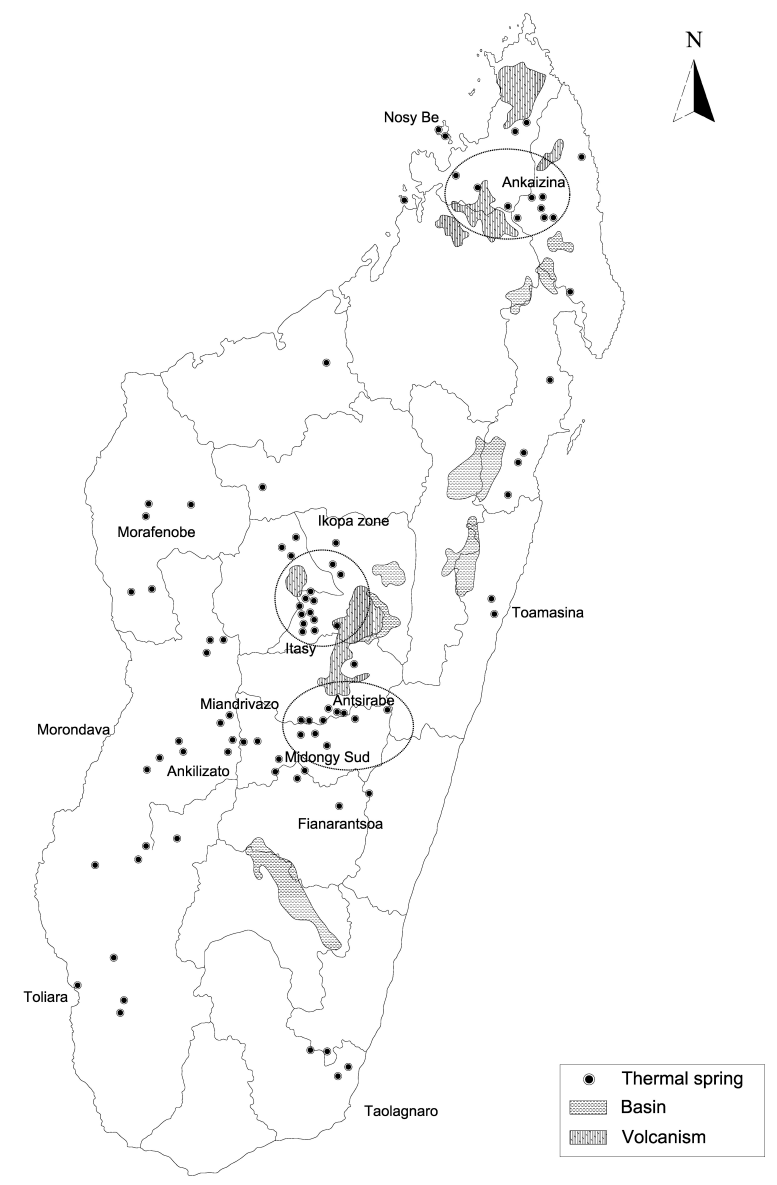

Figure 3: Localization of potential geothermal zones being likely to support geothermal power plants in Madagascar 
Though Madagascar has not yet reached advanced stages in surface exploration, a preliminary evaluation of temperatures indicates that most of the sites have relatively low to medium geothermal potential. Temperatures of the reservoir at depth are estimated to be between $75-152^{\circ} \mathrm{C}$ and were calculated using chalcedony geothermometer. Some of the reservoir temperatures of these magmatic-associated systems appear promising and may support geothermal power plants [23]. For example, in the geothermal field of Antsirabe, Sarazin et al. [24] have estimated the temperature at depth as $150^{\circ} \mathrm{C}$.

Hence, subsequent to Preliminary surveys, Andrianaivo and Ramasiarinoro [25] categorized three key zones that present interesting geothermal potentials for power production in this island, namely: the northern geothermal zone in the neighborhood of Ankaizina, the geothermal zone of Itasy, and the central parts of the Antsirabe geothermal zone (Figure 3). As a tentative estimate of the geothermal potential of this volcanic island, the value of $350 \mathrm{MW}$ was proposed [26].

\subsection{Hydropower}

With exactly a total area of $587,041 \mathrm{~km}^{2}$, Madagascar has a natural hydrographic network of over $3,000 \mathrm{~km}$ of rivers [27] that represents a renewable water resource of $337 \mathrm{~km}^{3}$ a year [28] suitable for power generation due to the relief configuration. The world small hydropower development reported in 2010 that, accordingly to GTZ-HERA-EUEI surveys, the electrification rate in Madagascar was still low, about $23 \%$ of which $60 \%$ in urban and less than $10 \%$ in rural areas; while the ADER stated that electrification rate was only of $10.56 \%$ in urban areas and $4.07 \%$ in rural areas [29]. In 2002, Hydro-Quebec Canadian company has identified around 7,800 MW of hydropower potential of Madagascar, and only $2 \%$ of this potential is exploited [10, 30, 31]. According to related surveys, there are more than 100 hydropower potential sites with an output capacity more than 50 MW and over 50 potential sites for that of more than 1,000 MW in Madagascar [32]. Main actor with over $77 \%$ of market share in the electricity production in Madagascar, JIRAMA public-managed company currently uses hydropower supported by thermal power plants using diesel motors to supply the electricity needs of users [14]. Hence, according to JIRAMA's database over the last fifteen years, the annual average of hydropower generation was $660 \mathrm{GWh} /$ year that represents $64.8 \%$ of all electricity produced in Madagascar with a total installed hydropower capacity of 105 MW; while some private micro-hydropower plants are working for rural electrification with an installed capacity less than $0.5 \mathrm{MW}[31]$. 


\subsubsection{Development status}

3.3.1.1. Large-scale hydropower.

The exploitation of Madagascar's hydropower resource is made up of two types of hydropower plants: large-scale hydropower plants with an installed capacity of more than $25 \mathrm{MW}$ and smallscale of hydropower plants with under $25 \mathrm{MW}$ size of installed power, with two plants options namely storage capacity and run-of-river. At the moment, JIRAMA company operates in the majority of hydropower plants of which the last great investment was that of Andekaleka, in 1982, with two turbines of $29 \mathrm{MW}$ each one [33]. Since then, a third turbine with a capacity of $33 \mathrm{MW}$ has been recently installed in 2012. Meanwhile, two other independent SHPs managed by private companies have strengthened the power production by JIRAMA with nominal powers of $15 \mathrm{MW}$ for Sahanivotry hydropower plant installed in 2008, and 5.4 MW for Tsiazompaniry hydropower plant exploited in 2010, and integrated in the interconnected network of the capital city Antananarivo. According to JIRAMA and ADER reviews, six sites for the construction project of hydropower plants in large-scale were identified [14]. A first phase of the study has already been carried out with the support of the World Bank to select the priority site. These large-scale hydropower potential sites are listed in table 3 .

Table 3: Projects of large-scale hydropower potential sites currently under study

\begin{tabular}{cclc}
\hline Site & Region & Facilities type & Installed power (MW) \\
\hline Antafofo & Betsiboka & Storage capacity & 160 \\
Mahavola & Analamanga & Storage capacity & 300 \\
Antetezambato & Vakinakaratra & Storage capacity & 180 \\
Lohavanana & Alaotra Mangoro & Run-of-river & 120 \\
Volobe Amont & Antsinanana & Run-of river & 90 \\
Sahofika & Alaotra Mangoro & Storage capacity & 300 \\
\hline
\end{tabular}

The realization of these large-scale projects is difficult or even compromised in the short and medium terms. Indeed, the implementation of such projects requires very thorough site data but also an expensive investment cost.

\subsubsection{Small-scale hydropower.}

Numerous potential sites have been identified for small-scale hydropower generation in Madagascar. 
The gross hydropower potential was evaluated about 5,600 MW for 700 potential sites relating the SPHs with an output capacity less than 10 MW. By the end of 2010, a project of 50 Small Hydropower Plants (SHPs) was supported [14]. Since 2004, ADER has encouraged private sector participation in rural electrification by developing local energy resource. In connection with the ADER, a French non-governmental organization, named GRET, implemented, from 2008 to 2012, the project Rhyviere Madagascar which consisted in conducting the feasibility studies of certain number of SHP construction projects [34]. In 2006, ADER still promoted projects of seven SHPs in a radius of over $120 \mathrm{~km}$ surrounding Antananarivo.

According to ADER surveys, 10 small-scale hydropower potential sites have been identified as shown in table 4 .

Table 4: Small-scale hydropower potential sites

\begin{tabular}{ccc}
\hline Site & Region & Installed power $(\mathrm{kW})$ \\
\hline Antsalova & Melaky & 100 \\
Andriana & Haute Matsiatra & 60 \\
Andrianabe & Sofia & 60 \\
Maheriara & Alaotra Mangoro & 350 \\
Marobakoly & Sofia & 600 \\
Sahatona & Haute Matsiatra & 220 \\
Mandalobe & Bongolava & 290 \\
Angodongodo & Ihorombe & 140 \\
Ankarinarivo & Amoron'i Mania & 80 \\
Androkabe & Alaotra Mangoro & 1,500 \\
\hline
\end{tabular}

The output capacity of these proposed SHPs does not exceed 1.5 MW, that means an increased attention to local electricity output development in rural and remote areas. Figure 4 shows the hydropower potential sites in Madagascar. These sites are spread across the country and their capacities varied from a few dozen to several hundred megawatts. 


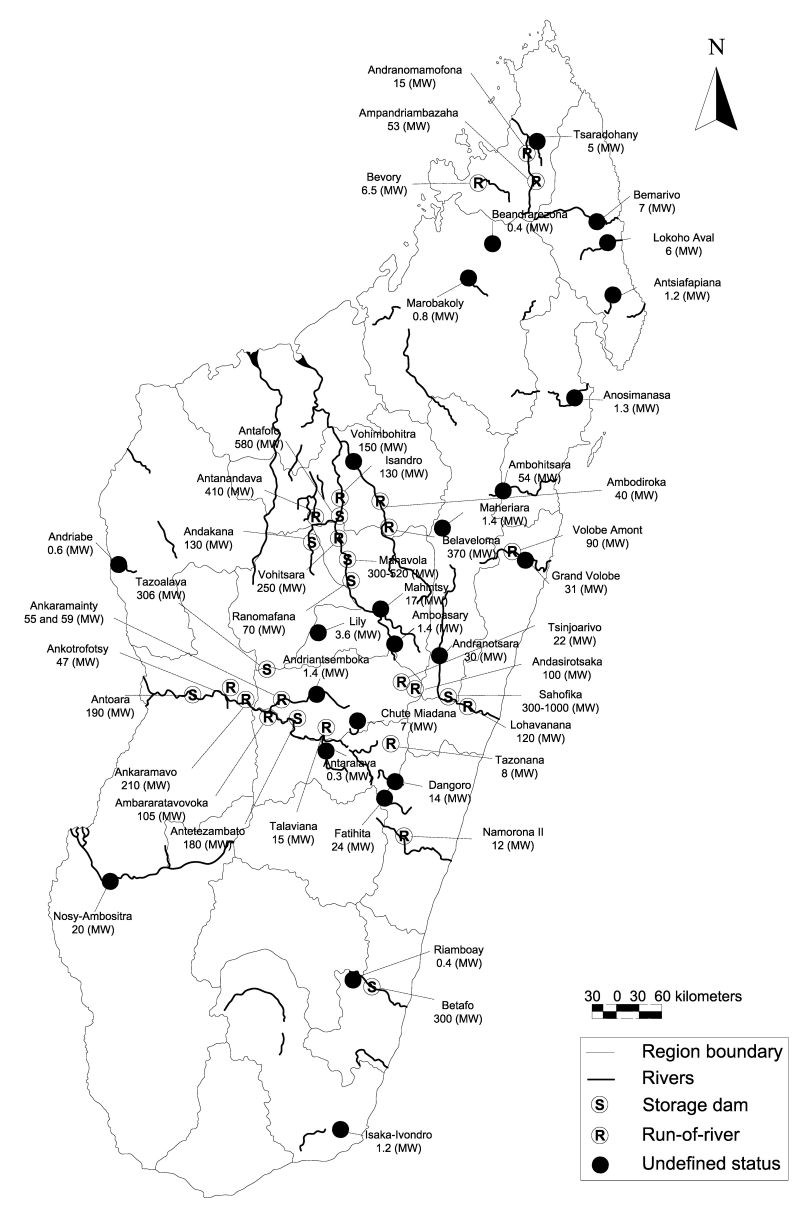

Figure 4: Hydropower potential sites in Madagascar

As can be seen in figure 4, these potential sites are mainly located in the central highlands where east and west slopes are separated by the great mountains of the highlands. With a surface area of $365,000 \mathrm{~km}^{2}$ representing $62.2 \%$ of the area of Madagascar [27], the west slope has numerous potential sites compared to the rest of the island. Besides, as no relevant data are available, the nature of some sites is still undefined although their hydropower potentials are known.

\subsubsection{Hydropower policy}

Based on Act no. 98-032 of January 20, 1999, national energy policy of Madagascar moved towards a reform of the energy sector, which allowed and encouraged a partnership between Malagasy Government and donors as well as other operators in funding the country's electric infrastructure and 
in promoting the service quality for the electricity end-users [31]. Accordingly, the national energy policy of Madagascar focuses in ensuring electricity supply security by developing hydropower in priority and by improving public-private partnership to establish a national guidelines in renewable energy research [30].

In 2009, the Ministry of Energy, taking in charge investment, development strategy policy and foreign assistance requests, has cooperated with ORE for a power source development [29]. From 2008 to 2012 , hydropower development program aimed to supply electricity to 8 rural communities of 14,000 inhabitants. Projects to use hydropower instead of diesel engines were discussed during the institutional capacity building, and were encouraged in order to manage strategic resources. In addition, increase of electricity pricing was observed along with that of fuel from 2005 to 2008 [35]. Since 2014, the public-private partnership has been enhanced to allow the implementation of the actions promoted by the Malagasy Government general policy [32]. While the electricity cost being currently around $0.04 € / \mathrm{kWh}[29]$ and the Malagasy currency continuing to depreciate, the challenge is to find a compromise to satisfy both tariff offers of power utilities providers and the users need [36].

For those purposes, it is expected that renewable energy, mainly including hydropower, occupies a share of $53 \%$ of the energetic mix of Madagascar by 2020 .

\subsection{Ocean energy}

The use of marine energies can be considered for Madagascar and particularly with OTEC, wave power and tidal barrages. The ocean current power or the tidal current turbines do not have potential for Madagascar [37].

\subsubsection{Ocean Thermal Energy Conversion (OTEC)}

OTEC allows the production of electricity using cold water from the deep seawater $(1000 \mathrm{~m}$ and $5^{\circ} \mathrm{C}$ and surface water as hot spring. With this small temperature difference $(\Delta T)$, it's possible to produce electricity with an ORC. Currently, experimental power plants are working on that subject and many studies have recently been initiated in France, Japan, South Korea and United States [38-42].

In fact, it is necessary to have a $\Delta T>20^{\circ} \mathrm{C}$ to run an OTEC plant. This $\Delta T$ is obtained at 6 to $10 \mathrm{~km}$ of the coast depending on the location (Table 5). The best site for offshore plant is the region of Andranovondronia. 
Table 5: Minimum distance between shore and $1000 \mathrm{~m}$ depth and annual mean temperature difference between surface water and deep water at $1000 \mathrm{~m}$ depth for Madagascar locations [37]

\begin{tabular}{lcc}
\hline Location & Distance $(\mathrm{km})$ & $\Delta T$ \\
\hline Andranovondronina & 6 & 21 \\
Masondrono & 8.2 & 21 \\
Ampondrabe & 8.7 & 22 \\
Vohemar & 9.3 & 21 \\
St Augustin & 8.4 & 20 \\
\hline
\end{tabular}

\subsubsection{Wave power}

Wave power is converted by devices with the energy from wind driven surface waves to electricity. Currently, many technical concepts are under development as [43]:

- Oscillating Water Column Systems

- Absorber Systems

- Overtopping Devices

- Inverted Pendulum Devices

- Other Wave Energy Systems, like PELAMIS [44]

In a preliminary study, wave power potential is measured in terms of energy density per wave crest $(\mathrm{kW} / \mathrm{m})$. Depending on the technologies, the resource needed will be different. Based on [43], wave power technologies are usually optimized for 15 to $35 \mathrm{~kW} / \mathrm{m}$.

Madagascar has a high potential for wave power, particularly in the southern of the island where the annual average achieves $50 \mathrm{~kW} / \mathrm{m}$, in the region of Tolagnaro.

\subsubsection{Tidal barrages}

Tidal barrages use the potential energy of tidal elevations. The principle is to capture a part of the tide and keep it out of phase with the natural tide and creating a difference in water level between the sea and the enclosed water. The water is allowed to even out by passing through a low head turbine. The device can be one way (ebb) or two-way operation (ebb and flood) [45]. It has been assumed that a mean tidal range of at least of $5 \mathrm{~m}$ is required for tidal barrages to be economically viable [46].

Because of the location of Madagascar, the oceanic tidal wave induces elevated tides over the East 
Africa continental coast and the Western of Madagascar, near Nosy Chesterfield.

The tides of the Western Madagascar coast are classified as macro-tidal, defined by [47], as spring

tidal range above $3 \mathrm{~m}$. It's not reaching the value of $5 \mathrm{~m}$ but a feasibility study conducted by Hammar et al. [37] shows that a tidal barrage in this location can have a temporal availability of power about $30 \%$ (\% of time).

\subsection{Solar energy}

Due to its location, Madagascar has a high solar energy potential. As shown in figure 5, the Global horizontal irradiation is $2000 \mathrm{kWh} / \mathrm{m}^{2}$. Almost all regions have more than 2800 hours (350 sunny days) of annual solar radiation. In the west coast, solar radiation ranges from 4000 to $6500 \mathrm{kWh} / \mathrm{m}^{2}$, [30]. Despite the potential of the solar resource, solar energy systems development remains difficult due to the large initial investment. Solar cookers have been developed in the south of Madagascar, [48]. 


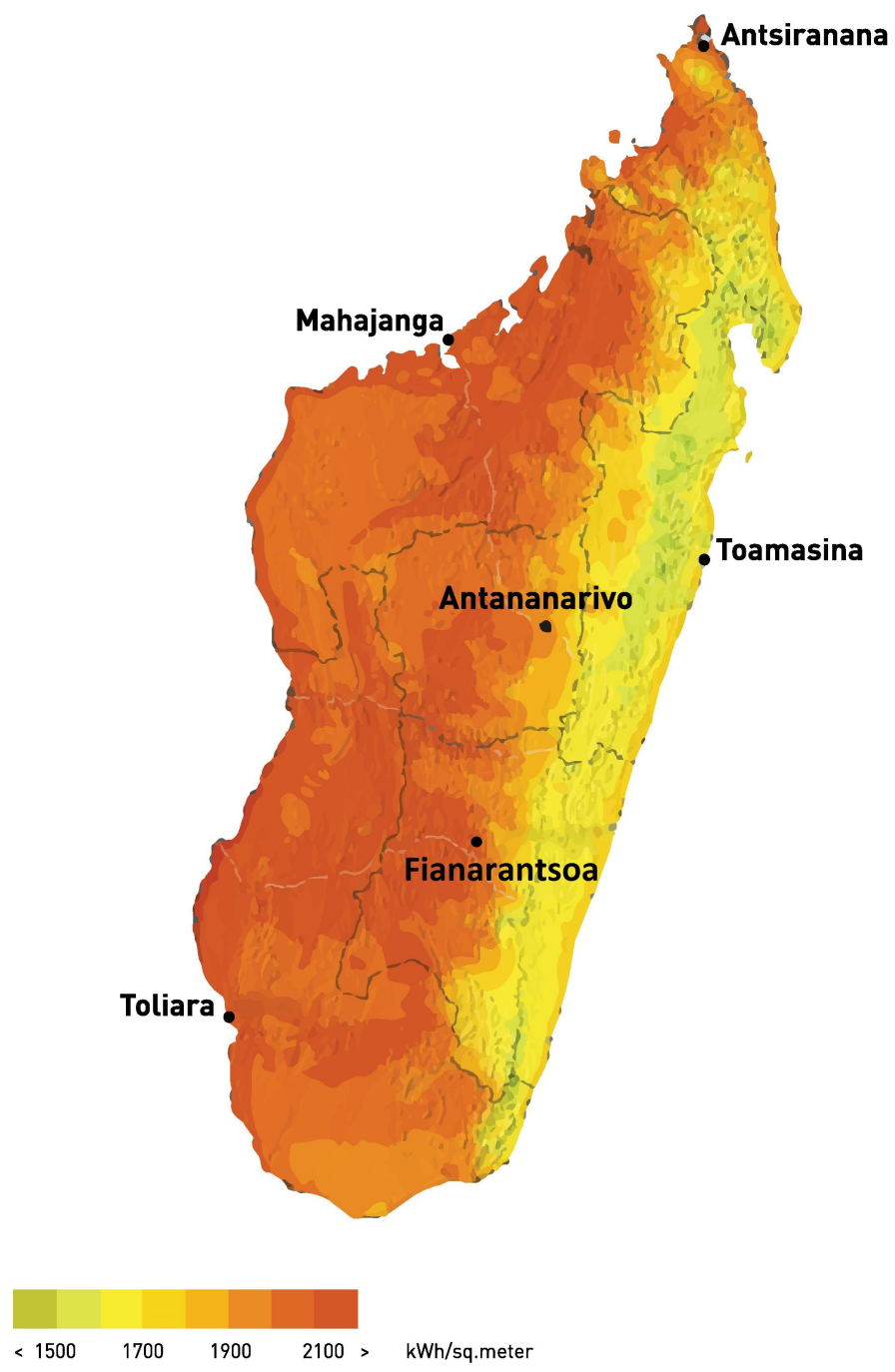

Figure 5: Global horizontal irradiation - Average annual sum, period 1994 - 2010,[49]

In Madagascar, solar energy facilities have recently been developed. Due to their cost, solar heating systems are not really enhanced. The photovoltaic system represents less than $1 \%$ of the power generation mix and has only been integrated since 2006. In March 2016, Madagascar joined the World Bank Group's Scaling Solar program. About 30 - 40 MW solar plants are planned in this program in order to reduce daily load shedding and interruptions of electricity distribution. Solar energy is used to develop rural electrification. Furthermore, thanks to a photovoltaic rural electrification, about 20000 inhabitants have access to electricity by the help of the BOREALE 
project [50].

\subsection{Wind energy}

Madagascar has an important wind energy potential. Indeed, with three kinds of winds: the coastal winds, the local wind and the ocean wind such as the trade wind and the cyclones, Madagascar can reach a wind energy potential of about $2000 \mathrm{MW}$. With respectively a daily variation and a seasonal variation, the local and coastal wind and the trade wind constitute a reliable source of wind energy [30]. This important wind energy potential is mainly located in the north with a wind speed higher than $8 \mathrm{~m} / \mathrm{s}$, in the south with wind speed exceeding $7.5 \mathrm{~m} / \mathrm{s}$ and in the east coast of the island with an average wind speed of $6.5 \mathrm{~m} / \mathrm{s}$ [51]. However, frequent cyclones (one to five per season) in this east part of the country might be an obstacle for wind energy development. Hence, the North, the South and the East coast of Madagascar are considered to be the windiest part of the country and therefore have a high potential for wind energy development. This statement is confirmed by the wind atlas (see figure 6) supplied by the ADER [52]. It shows the wind speed repartition according to the elevation, 50 or $10 \mathrm{~m}$. 

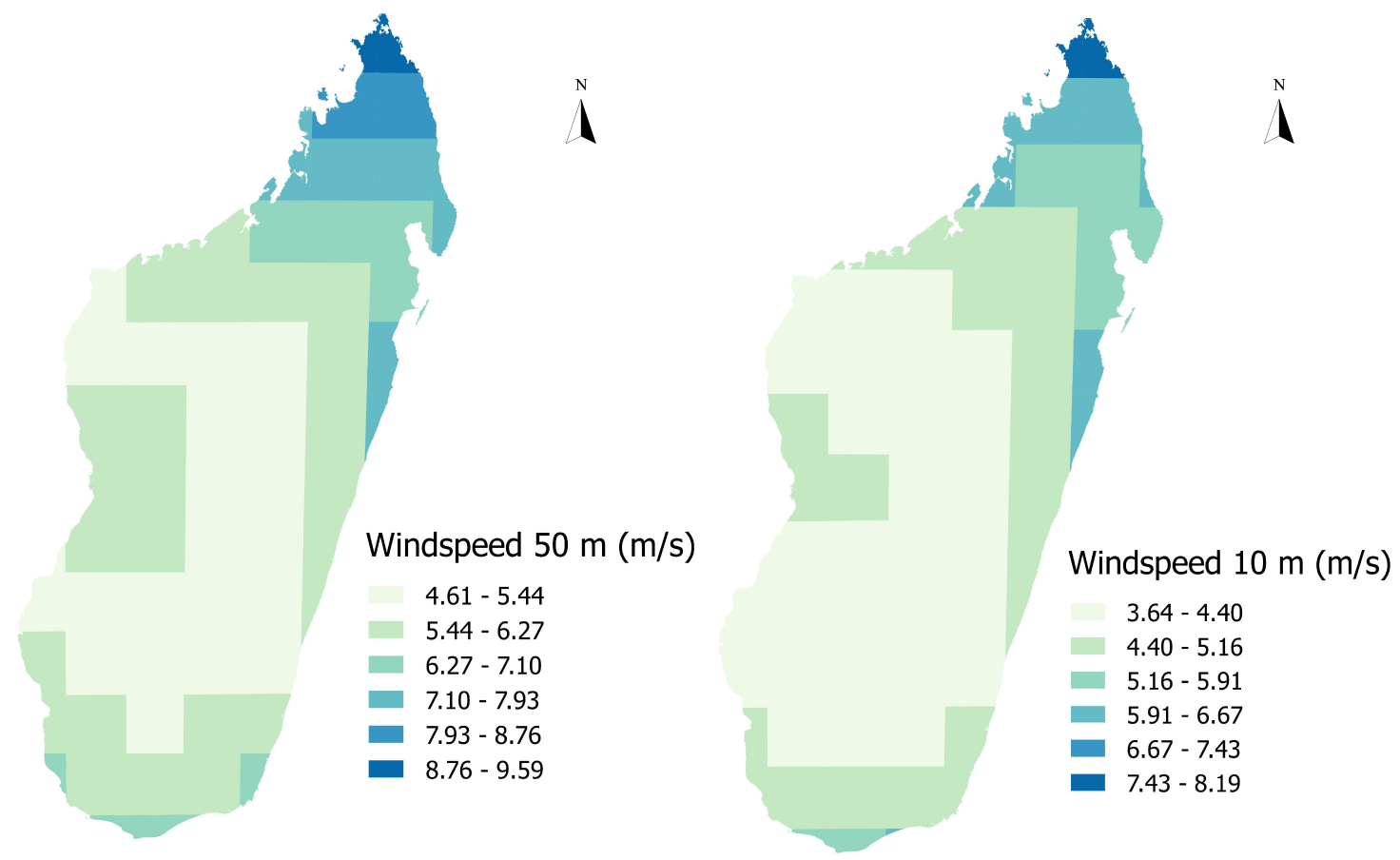

Figure 6: Wind speed atlas of Madagascar

The wind atlas confirms the potential in the coast, with a decrease of wind speed in the highland. This wind speed deceleration in the center is due to the vegetation influence but also due to the relief (see figure 7). Indeed, the highland has an elevation of about 800 to $1500 \mathrm{~m}$ which decrease considerably the wind speed. Hence, one can state that the regions with higher wind energy potential are located in extreme south and north [51].

In the north, an average wind speed of $8 \mathrm{~m} / \mathrm{s}$ at an elevation of $50 \mathrm{~m}$ and $10 \mathrm{~m}$ can be reached. Three regions can take advantage of this situation: Diana and Sava (see figure 7 for administrative region distribution). For the region of Diana which has a high density of population (cities of Cap Diego and Antsiranana), high wind energy potential and a good connection to other parts of the country, the wind energy constitutes an important way to the economic development of this area. In the center, and mainly in the east coast, the wind potential is about $6 \mathrm{~m} / \mathrm{s}$, however, two obstacles are to be taken into account: the cyclones and the vegetation. As stated earlier, one to five cyclones per year pass through this area during the austral summer, and as wind turbines 
cannot stand cyclones, special precautions should be taken for wind turbines installed in this area. Besides, due to vegetation density, areas with "clear" vegetation should be chosen for an optimal wind speed.

Table 6: Region and locality with high wind energy potentiality [53]

\begin{tabular}{ccc}
\hline Region & Locality & Potentiality $(\mathrm{m} / \mathrm{s})$ \\
\hline Atsimo Andrefana & Itampolo, Androka, Tanjona, Ambohimena & 8 to 9 \\
Androy & Tsihombe & 8 \\
Anosy & Lokaro a tolagnaro & 8 to 9 \\
Diana & Nosy Be, Cap Diego and Antsiaranana & 9 \\
Sava & Sambava, North of Antsirabe and Manambato & 7.5 \\
\hline
\end{tabular}

In the south, an average potential of $6 \mathrm{~m} / \mathrm{s}$ of wind speed is stated and maximum potential is mainly located in the extreme south region of the county. The south of Madagascar has an arid climate with a low population density. Also project with autonomous wind turbines (for water or electricity) should be privileged to open up this region to the rest of the country [51]. 

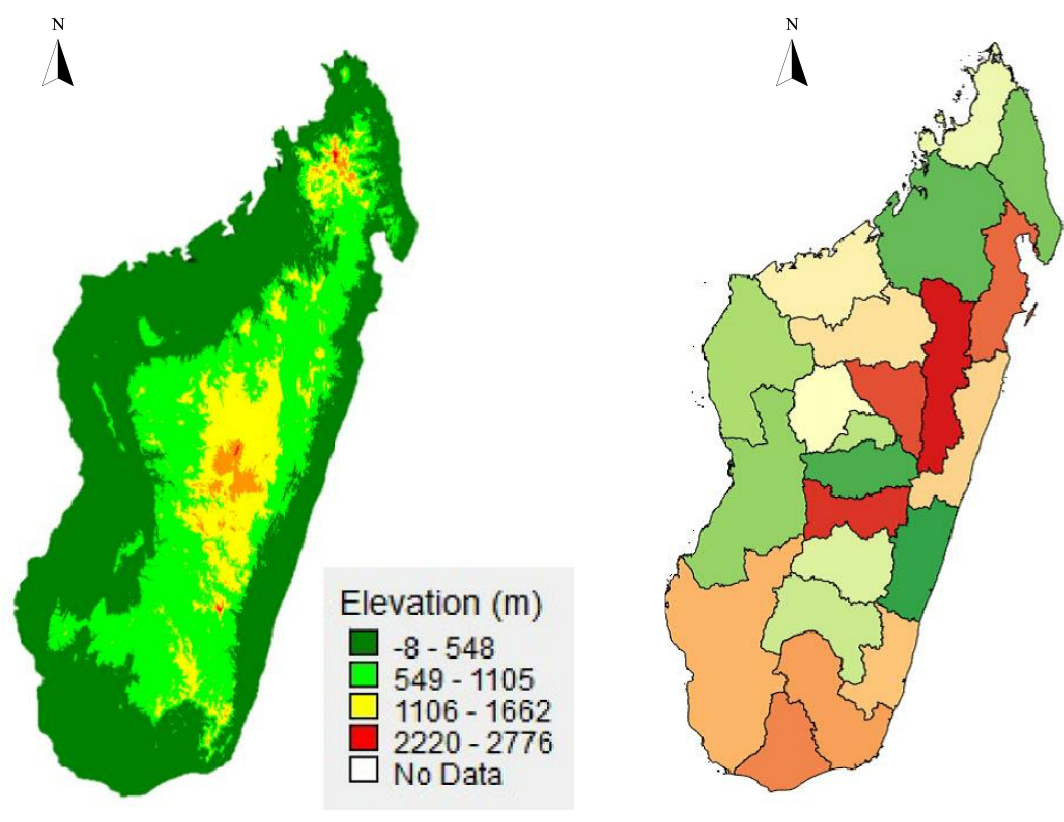

Administrative region

- Alaotra-Mangoro

$\square$ Amoron'i mania

$\square$ Analamanga

$\square$ Analanjirofo

$\square$ Androy

$\square$ Anosy

$\square$ Atsimo-Andrefana

$\square$ Atsimo-Atsinana

$\square$ Atsinanana

$\square$ Betsiboka

$\square$ Boeny

$\square$ Bongolava

$\square$ Diana

$\square$ Haute matsiatra

$\square$ Ihorombe

$\square$ Itasy

$\square$ Melaky

$\square$ Menabe

$\square$ Sava

$\square$ Sofia

$\square$ Vakinankaratra

$\square$ Vatovavy Fitovinany

Figure 7: Elevation and administrative region in Madagascar

The north region of the island concentrates the main wind energy projects because of higher po-

tential, as seen in the table 6. Two kinds of facilities are currently in use in Madagascar, namely water pumping wind turbines and electric ones. Both are mainly imported and only assembly is made locally [30].

There is a few number of wind turbines in Madagascar for water pumping and only one provider on the market. For electric wind turbines, some companies already exist in the Malagasy market and the most important ones are SOMECA which can provide wind turbine up to $275 \mathrm{~kW}$, SOLARMAD which is a Franco-Malagasy company and produces $500 \mathrm{~W}$ to $1.5 \mathrm{~kW}$ wind turbine with nominal performance at a wind speed of $7 \mathrm{~m} / \mathrm{s}$ and TED which imports wind turbines from the USA from $400 \mathrm{~W}$ to $3 \mathrm{~kW}$. For large scale rural electrification, projects in collaboration with local institutions especially the ADER to promote the use of renewable energy and wind energy in rural area are undertaken. Among those projects, we can mention the Mad' EOLE project which is funded by $30 \%$ by ADER and $70 \%$ by private part. This project began with the electrification of the village of 
Sahasifotra in the region of Diana (Northern part of the country) in 2007. 60 families representing 300 people were electrified. The system is made of 3 wind turbines of $5 \mathrm{~kW}$, lowered in case of cyclones. These wind turbines work with a battery and are accompanied by a diesel generator of 5 $\mathrm{kW}$.

Since, other projects have been undertaken in other villages which are chosen according to their wind regimes, their village structures, their economic potential and the engagements of the population. Among them, we can notice the village of Ambolobozikely and Ambolobozibe electrified respectively with $20 \mathrm{~kW}$ and $50 \mathrm{~kW}$ wind turbines for a total of 2460 inhabitants (table 7 ). However, the largest wind energy exploitation is located in the south in the village of Andohan' Ilakaka in the region of Ihorombe with an $80 \mathrm{~kW}$ power wind turbine. Despite the fact that this region (west) is not among those which have a high potential of wind energy, the site was windy enough for the project. Also, there are some sites in the center where their special disposition in terms of relief and vegetation, have a high wind energy potential.

Table 7: Projects in collaboration with ADER

\begin{tabular}{cccccc}
\hline Project & Region & Locality & Year & Wind energy exploited $(\mathrm{kW})$ & Number of population \\
\hline MAD'EOLE & Diana & Ivovona & 2010 & 15 & 740 \\
MAD'EOLE & Diana & Ambolobozikely & 2010 & 20 & 730 \\
MAD'EOLE & Diana & Ambolobozibe & 2010 & 30 & 1360 \\
SEEM & Ihorombe & Andohan'Ilakaka & $2002 / 2009$ & 80 & 3800 \\
\hline
\end{tabular}

However, the issues of wind energy development in Madagascar lie in three main points namely, the commercial and financial barriers, the distance between the potential site and the consumption place, and the low population density. Indeed, the lack of sufficient volume in the market for technology providers and a high upfront investment costs for wind energy technologies is an important disadvantage compared to the low cost and quick installation of diesel base system. Furthermore, the distance from the potential wind sites are far away from the village and an extra expense for transport lines is required which increases the cost of wind energy development. Moreover, in rural areas, houses are spread out throughout the villages. This situation increases distribution costs and is made worse by the households' low payment capacity. Hence, low charge rate leads to high $\mathrm{kWh}$ price. In order to promote wind energy, local authorities should apply tax exemption on 
material related to wind turbine construction and tax reduction for firm which intend to invest in wind energy in Madagascar [30]. However, despite this regulation on renewable energy material and equipment, renewable energy is still expensive for the average Malagasy people in terms of price, installation and maintenance compared to "plug and play" gasoline generators.

\section{Electricity projections}

The aim of this section is to present a general assessment of the facilities in the national grid, the evolution of electricity generation and consumption in order to illustrate the current energy trend. To reach the goals that have been set during the Conference of the Parties in Paris in 2015 for Madagascar, it is necessary to observe the evolution of the current status if no measure is taken. It should be noted that Madagascar's challenges refer to preserve forests in order to reduce by $14 \%$ the GHG emission and to improve The situation trend and the related greenhouse gas (GHG) emission are described in the second and third part of the section.

\subsection{Electricity mix current status}

JIRAMA electricity production essentially depends on fossil fuel and hydroelectric resources. In

- Hydropower plants, including small and large scale installations, whose total power is up to $170 \mathrm{MW}$

- Thermal power plants including heavy fuel and petrol engine, whose total power installed throughout the country is up to $345 \mathrm{MW}$;

- Solar photovoltaic system of $7 \mathrm{~kW}$ power located in the south part of Madagascar, since 2006.

Funded by ADER, implementation of rural electrification projects mainly depends on partnership with private operators. According to a diagnostic report of the MEM [54], ADER counted about 140 electrification projects from 2004 to 2012 . It promotes the production of electricity from renewable energies, even if $75 \%$ of the total project is essentially composed by thermal power plants. Referring to the MEM diagnosis [14], table 8 lists the different plants implemented by ADER . 
Table 8: Electricity power plants implemented by ADER, by resources

\begin{tabular}{lr}
\hline Energy resources & Power installed $(\mathrm{kW})$ \\
\hline Thermal power & 3159 \\
Hydropower & 788 \\
Wind energy & 145 \\
Biomass & 94 \\
Solar energy & 14 \\
\hline Total & 4200 \\
\hline Source
\end{tabular}

Source: ADER 2012

Electricity production has steadly grown since 2002 as can be seen in table $9[54,57]$, the total production in 2002 was about $780 \mathrm{GWh}$, it has reached to $1350 \mathrm{GWh}$ in 2012 , corresponding to an average yearly increase of about $6 \%$. With regard to power consumption, a growth rate of $58 \%$ was noticed during the above-mentioned ten years period. It is worth noting that, due to lack of information from rural electrification, these values are only imputed to JIRAMA's production. The consumption/production ratio equals $75 \%$ in 2002 ; it decreased to $68 \%$ in 2012 , as can be seen from table 9 . Due to political crisis of 2009 , there was a decline of energy consumption as many industrial companies suspended their activities until the crisis was over.

Energy production from fossil fuels represents an average annual growth of $9.79 \%$ and its contribution into the electric mix reached to $43.43 \%$ in 2012 , while it was only $31.36 \%$ in 2002 . On the other side, it can be seen that hydropower production is almost stable with a slight average annual growth of $3.7 \%$. Energy production from photovoltaic system remains a marginal part of the total production. Renewable energies part into the national energy production is about $56.57 \%$, despite the high potential of renewable energies presented by the whole territory and described in the foregoing paragraphs. 
Table 9: Overview of electricity production and consumption in Madagascar from 2002 to 2012

\begin{tabular}{lrrrrrrrrrrr}
\hline & 2002 & 2003 & 2004 & 2005 & 2006 & 2007 & 2008 & 2009 & 2010 & 2011 & 2012 \\
\hline Production (GWh) & & & & & & & & & & & \\
Hydropower & 535 & 612 & 637 & 648 & 638 & 719 & 700 & 740 & 711 & 690 & 755 \\
Fossil fuels & 245 & 287 & 346 & 341 & 366 & 332 & 404 & 363 & 479 & 577 & 595 \\
Solar energy & - & - & - & - & 0.004 & 0.004 & 0.007 & 0.006 & 0.008 & 0.008 & 0.008 \\
Total & 780 & 898 & 983 & 988 & 1004 & 1051 & 1104 & 1103 & 1190 & 1268 & 1350 \\
\hline Consumption (GWh) & 585 & 675 & 754 & 754 & 778 & 784 & 852 & 791 & 844 & 883 & 926 \\
\hline Source: Jor
\end{tabular}

With a total country population of some 22 millions in 2012, the average size of a household has 4.8 people, referring to the INSTAT ${ }^{11}$ or National Institute of Statistics or National Institute of Statistics report [58]. At national level, the situation on the connection to the electricity masks inequalities depending on the environment. In fact, the national electrification rate is estimated at $12.3 \%$ (39\% in urban areas, and less than 5\% in rural areas) in 2010 [14]. In 2013, Madagascar has $14 \%$ rate level [59] .

The customers are divided in two categories: customers in Low Voltage (LV) and customers in High/medium Voltage (HV), which represent respectively $99 \%$ and $1 \%$ of the total customers [57]. The average electricity consumption of each category is about $1.282 \mathrm{MWh} / \mathrm{LV}$ customer and 341 MWh/HV customer, in 2012. Referring only on the number of population, Madagascar presents an electricity consumption per head of about $41 \mathrm{kWh} /$ year, in 2012.

\subsection{A business-as-usual consumption scenario}

Considering a business-as-usual configuration, this section focuses on the estimation of electricity demand until 2050. As regarding the following key values issue, we consider that these parameters will not present substantial changes:

- the population growth will be taken from data on the World Population Prospects in 2013, and represents high, medium and low evolution [60];

- the electrification rate in 2012 is taken equal to $14 \%$ with an annual increase of $3 \%$, based on the International Energy Agency (IEA) report [59];

\footnotetext{
${ }^{11}$ « Institut National de la STATistique » or National Institute of Statistics
} 
- customers refer to all subscribers in LV and HV. To note that a LV subscriber represents a household. We consider that the LV and HV proportion is as the same as current situation. The consumption ratio is taken as 1.282 $\mathrm{MWh} / \mathrm{LV}$ customer and $341 \mathrm{MWh} / \mathrm{HV}$ customer.

Projected values are calculated taking into account the aforementioned assumptions. The total electricity needs resulted by the multiplication of population value, the electrification rate, and the consumption ratio for each subscriber category. According to our calculations for the year 2050, urban population connected to JIRAMA's electric network will need an electric energy of 7,616 GWh, in the case of a high population growth and at least, 5900 GWhin low population growth. Based on these calculations, electrification rate of the territory increases by $81 \%$, from $14 \%$ in 2012 to $25.4 \%$ in 2050 . Therefore, the electricity consumption per capita will also increase $(41 \mathrm{kWh} /$ capita in 2012 and $121 \mathrm{kWh} /$ capita in 2050). Table 10 summarizes the results related to the period from 2012 through 2050.

500

Table 10: Results of evolution scenarios: population, customers, consumption

\begin{tabular}{l|rrr|rrr|rrr}
\hline & \multicolumn{3}{|c}{ High scenario } & \multicolumn{4}{c}{ Medium scenario } & \multicolumn{3}{c}{ Low scenario } \\
\hline & Population & Customers & $\begin{array}{r}\text { Cons } \\
(\mathrm{GWh})\end{array}$ & Population & Customers & $\begin{array}{r}\text { Cons } \\
(\mathrm{GWh})\end{array}$ & Population & Customers & $\begin{array}{r}\text { Cons } \\
(\mathrm{GWh})\end{array}$ \\
\hline 2012 & 22359659 & 456422 & 926 & 22359659 & 456422 & 926 & 22359659 & 456422 & 926 \\
2015 & 24444712 & 758805 & 1738 & 24235390 & 752307 & 1723 & 24026069 & 745809 & 1708 \\
2030 & 37883791 & 1531137 & 3507 & 36000163 & 1455007 & 3333 & 34122913 & 1379134 & 3159 \\
2050 & 62835889 & 3325066 & 7616 & 55497589 & 2936747 & 6727 & 48680455 & 2576007 & 5900 \\
\hline
\end{tabular}

\subsection{Environmental impact assessment}

In this section a life cycle assessment (LCA) approach has been used in order to evaluate the potential environmental impacts, due to the electricity generation, [61]. This approach was intend to evaluate the impacts of annual generated electricity, if no measure are taken. Regarding the environmental impacts of the power production, according to the EIA data [62], Madagascar has recorded a total of 2.89 million metric tons of $\mathrm{CO}_{2}$ from consumption of fossil fuels, all sector gathered. Electricity production represents $15 \%$ of the total emissions of $\mathrm{CO}_{2}$ recorded in Madagascar (492 kt $\left.\mathrm{CO}_{2}-\mathrm{eq}\right)$. Thus, in 2012, Malagasy electricity has an emission factor of $463 \mathrm{~g} \mathrm{CO}_{2}-\mathrm{eq} / \mathrm{kWh}$. In 2012, renewable energies represent $56.57 \%$ of the electricity mix, although Madagascar has a 
high but underexploited potential. Considering the high potential in hydropower, the retained assumptions are a climb of $15 \%$ for the hydropower and $5 \%$ for the photovoltaic production, until 2050. To note that the other renewable energies are not included in the assumptions, if we keep a business-as-usual scenario. However, hydropower and photovoltaic system may benefit of a moderate increase, with a view of a continued care and a maintenance of the existing facilities. Subsequently, a decline of the fossil fuel part was assumed though it remains consistent with $25 \%$ of the total power production.

For the emissions assessment, we have considered the GEMIS tool and its database in its 4.9 version, in order to identify a cradle-to-gate emission [63]. GEMIS is a LCA tool used by many parties in more than 30 countries for environmental, cost and employment analyses of energy, materials and transport systems. As no energy process for Madagascar is available, we considered the generic ones, for fuel oil steam turbine and diesel combustible engine and hydrodam power plant. Reflecting Malagasy conditions and the efficiencies, transport of raw materials have been included in the process. The methodology used consists to multiply the amount of electricity to be produced from each energy system by its emission factor to obtain the total amount of GHG emission.

The results represent the global warming potential (GWP) of the production, including the main GHG such as $\mathrm{CO}_{2}, \mathrm{CH}_{4}$ or $\mathrm{N}_{2} \mathrm{O}$. Emission factors based on GEMIS software data are as follows: $25.87 \mathrm{~g} \mathrm{CO}_{2}-\mathrm{eq} / \mathrm{kWh}$ for hydropower plants, $1032.27 \mathrm{~g} \mathrm{CO}_{2}-\mathrm{eq} / \mathrm{kWh}$ for heavy oil and diesel power plants, and $95.59 \mathrm{~g} \mathrm{CO}_{2}-\mathrm{eq} / \mathrm{kWh}$ for photovoltaic system. The power plants'infrastructures were considered for these emission factors and the calculation referred to the low heat value. Emissions for renewable energies are generally imputed to the construction.

Table 11: Results of electricity consumption and the related GWP emissions 2012-2050

\begin{tabular}{r|rr|rr|rr}
\hline & \multicolumn{2}{|c}{ High scenario } & \multicolumn{2}{c}{ Medium scenario } & \multicolumn{2}{c}{ Low scenario } \\
\hline & Consumption & GWP & Consumption & GWP & Consumption & GWP \\
& GWh & $\mathrm{kt} \mathrm{CO}_{2}-$ eq & GWh & $\mathrm{kt} \mathrm{CO}_{2}-$ eq & GWh & kt $\mathrm{CO}_{2}-$ eq \\
\hline 2012 & 926 & 429 & 926 & 429 & 946 & 429 \\
2015 & 1738 & 780 & 1723 & 773 & 1708 & 766 \\
2030 & 3507 & 1321 & 3333 & 1256 & 3159 & 1190 \\
2050 & 7616 & 2140 & 6727 & 1890 & 5900 & 1658 \\
\hline
\end{tabular}

According to the above scenario results, electricity consumption in the country in 2050 could reach 
nearly 8 times the consumption in 2012, while greenhouse gas emissions could increase fivefold. According to the values on table 11, the emission factor per produced $\mathrm{kWh}$ will decrease by $40 \%$ compared to 2012's rate, $280 \mathrm{~g} \mathrm{CO}-\mathrm{eq} / \mathrm{kWh}$ in 2050 versus $463 \mathrm{~g} \mathrm{CO}_{2}-\mathrm{eq} / \mathrm{kWh}$ in 2012 , for all the scenario. These values are obtained by dividing the total amount of emissions by the electricity needs. The emission factor remained unchanged for all the scenarios, due to the assumptions in the electric mix composition. By 2030, the emission factor decline represented 19\%. Considering the emission rate per head in 2012 (19.17 kg CO $2-$ eq/capita), an increase of $78 \%$ will be observed in 2050 (34.05 $\mathrm{kg} \mathrm{CO}-$ eq/capita). We can observe that the increase in the use of RES is going to lead to a reduction of the emission factor, even though only production from the existing facilities have been improved.

\section{Barriers to RES development}

Madagascar still heavily depends on fossil energies namely wood and fuels. Up to now, the exploitation of renewable energy sources remains marginal for power generation. The development of these RES was constrained by technical, economic and political troubles which depend on several factors $[31,64]$ such as currency value fluctuation on the international market accessibility issues. Other main barrier for RES potential development involves the lack of funding. Countries that have affordable and reliable energy resources with clear legal and regulatory framework can more easily attract both foreign and domestic capital investments. However, the achievement of the national energy policies is still far from enough for Madagascar. The country has high potential in renewable energy that may improve economic situation and social development. Nevertheless, most RETs projects are embryonic or in preliminary study phase, and do not allow large-scale implementation. For geothermal energy, the drawbacks are associated with characteristics of the available resources [22] that are mostly unknown involving a high degree of uncertainty around investment costs. Added to that, the research sector is isolated, when no feedback can be done without updated data. For hydropower generation, SHPs development barriers relate to the lack of funding, lack of national transparency standard of commercialization and defined national electricity grid [29]. In rural and remote areas, the barriers are related to the distribution of electricity, including the technical means of transmission and consumption metering. In fact, the GDP or Gross Domestic Product is still low in the country, the cost of power poles and electric meters are unaffordable for most Malagasy 
farmers even though the villagers try to come together to share the cost of such equipment. Though Madagascar has huge solar and wind potentials, RETs may not generate expected returns regarding national energy targets due to high operation and initial investment costs. It is also obvious that the technical know-how is not enough to the point that it does not adequately meet the objectives of the development of both abovementioned RES in Madagascar. The same barrier also applies to biomass due to lack of capacity building to develop this sector.

For all the aforementioned barriers, updating of national energy policy is imperative in order to ensure consistency between local initiatives and national guidelines for RES development.

A coherent approach for RES is necessary and crucial for the future of Madagascar. Actually, the country has to face two challenges at the same time. The first one is to significantly increase its electricity production due to an important growth of both population and electrification rate. The second is to define and adopt a strategy to decarbonizing the electricity power. This two challenges are particularly in Madagascar because its low standard of living. Thus, the government seems not to have made a priority to define and adopt a sustainable energy planning.

\section{Conclusion}

For insular territory, reducing the dependency on fossil fuels for electricity generation is both a main issue and the first step to the road map of sustainable development. Madagascar, also called "The big island" is no exception to the rule. Enhancing the access to electricity is a key point for the socioeconomic development of any country. The island has to face many challenges at the same time (economy, health, policy, energy, etc). Madagascar has not yet completed its demographic transition and will have to ensure effective planning and management of its energy transition.

The access to electricity is particularly dichotomous between rural region and main urban areas such as Antananarivo, Diego, Majunga. Since 2001, the rural electrification has been the focus of many non-governmental organizations or private investors. In order to raise the electrification rate from $4.8 \%$ to $10 \%$ in 2020, an annual investment of 10 million euros will be necessary. This paper has firstly proposed a detailed overview of the energy sector situation in Madagascar, and clearly highlights the high potential of renewable energy sources on the territory. Despite the numerous existing challenges in the energy sector, this paper has shown that opportunities abound. Hydropower, wind and solar energies appear as the main RES that could strongly and widely ensure 
the power generation in the country for the future. Nevertheless, the ability of Madagascar to deal with exogenous energy shocks is currently severely curtailed.

The most obvious obstacle of renewable energy deployment is mainly the economic situation and structure of the island. Indeed, $50 \%$ of the population is still living below the poverty line and $92 \%$ of Malagasy live on less than 2 dollars a day. Hence it becomes complicated to require any financial contribution from the population. Thus, it seems clear that only a proactive development policy for the government could really put the country on the path towards change. A first step is to define new policy which could facilitate the implementation of these renewable technologies in Madagascar. The next step, that so often lack, is to change political discourses into real actions on the ground. In the next years, a significant contribution will be to state an energy roadmap, which defines each phase to pass through to suceed its energy transition.

Finally, as Madagascar is the fourth largest island in the world, many remote regions are still existing. Thus, the strategy of RES deployment should probably encourage small interconnected grid in regions than unique national grid on the territory. Once a stable and integrated development environment for regional production is achieved, an interconnection between sub territories could be considered.

\section{Acknowledgements}

The authors gratefully acknowledge the support funding from the Agence Universitaire de la Francophonie (AUF) that made this collaboration between researcher from Madagascar and Reunion island possible. The author would also like to thank the kind collaboration of Ministry of Energy of Madagascar, JIRAMA and INSTAT for the access to database.

\section{References}

[1] N.-A. Spyridaki, A. Flamos, A paper trail of evaluation approaches to energy and climate policy interactions, Renewable and Sustainable Energy Reviews 40 (2014) $1090 \quad-\quad 1107$. doi:http://dx.doi.org/10.1016/j.rser.2014.08.001.

URL http://www.sciencedirect.com/science/article/pii/S1364032114006765

[2] B. Wang, R.-Y. Ke, X.-C. Yuan, Y.-M. Wei, Chinas regional assessment of renewable energy vulnerability to climate change, Renewable and Sustainable Energy Reviews 40 (2014) 185 - 195. doi:http://dx.doi.org/10.1016/j.rser.2014.07.154.

URL http://www.sciencedirect.com/science/article/pii/S1364032114006066 
$$
\text { electricity, Oficial Journal of Madagascar (2002). }
$$

[14] Ministry of Energy and Mines (MEM) and WWF, Diagnostic du secteur énergie à madagascar, Tech. rep. (2012).

[15] A. Voninirina, S. Andriambelosoa, Etude sur l'energie à madagascar, Tech. rep., Centre de recherches d'études et d'appui à l'analyse économique à Madagascar (CREAM) (2014).

[3] P. Thollander, O. Kimura, M. Wakabayashi, P. Rohdin, A review of industrial energy and climate policies in japan and sweden with emphasis towards \{SMEs\}, Renewable and Sustainable Energy Reviews 50 (2015) 504 - 512. doi:http://dx.doi.org/10.1016/j.rser.2015.04.102.

URL http://www.sciencedirect.com/science/article/pii/S136403211500372X

[4] J. Z. Thellufsen, H. Lund, Roles of local and national energy systems in the integration of renewable energy, Applied Energy 183 (2016) 419 - 429. doi:http://dx.doi.org/10.1016/j.apenergy.2016.09.005.

URL http://www.sciencedirect.com/science/article/pii/S0306261916313071

[5] T. B. Tsuchida, Chapter 24 - renewables integration on islands, in: L. E. Jones (Ed.), Renewable Energy Integration, Academic Press, Boston, 2014, pp. 295 - 305. doi:http://dx.doi.org/10.1016/B978-0-12-4079106.00024-7.

[6] V. Oree, S. Z. S. Hassen, P. J. Fleming, Generation expansion planning optimisation with renewable energy integration: A review, Renewable and Sustainable Energy Reviews 69 (2017) 790 - 803. doi:http://dx.doi.org/10.1016/j.rser.2016.11.120.

URL http://www.sciencedirect.com/science/article/pii/S1364032116308711

in: L. E. Jones (Ed.), Renewable Energy Integration, Academic Press, Boston, 2014, pp. 203 - 211. doi:http://dx.doi.org/10.1016/B978-0-12-407910-6.00016-8.

URL http://www.sciencedirect.com/science/article/pii/B9780124079106000168

[8] B. Zakeri, S. Syri, S. Rinne, Higher renewable energy integration into the existing energy system of finland - is there any maximum limit?, Energy 92, Part 3 (2015) 244 - 259, sustainable Development of Energy, Water and Environment Systems. doi:http://dx.doi.org/10.1016/j.energy.2015.01.007.

URL http://www.sciencedirect.com/science/article/pii/S0360544215000146

[9] International Energy Agency (IEA), Africa energy outlook - a focus on energy prospects in sub-saharan africa, Tech. rep. (2014).

[10] United Nations Development Programme, Madagascar - national report, Tech. rep. (2012).

[11] W. Bank, Doing Business 2016: Measuring Regulatory Quality and Efficiency, World Bank Publications, 2015.

[12] Republic of Madagascar, Act no. 98-032 of january 20, 1999 referring to electricity sector reform, Official Journal of Madagascar 2560 (1999) 795.

[13] Republic of Madagascar, Act no. 2002-001 of october 7, 2002 referring to creation of the national funding of electricity, Official Journal of Madagascar (2002).

6] J. Painuly, Barriers to renewable energy penetration; a framework for analysis, Renewable Energy 24 (1) (2001) 73 - 89. doi:http://dx.doi.org/10.1016/S0960-1481(00)00186-5.

URL http://www.sciencedirect.com/science/article/pii/s0960148100001865 
[17] J. Painuly, H. Park, M.-K. Lee, J. Noh, Promoting energy efficiency financing and \{ESCOs\} in developing countries: mechanisms and barriers, Journal of Cleaner Production 11 (6) (2003) 659 - 665, financing Cleaner Production. doi:http://dx.doi.org/10.1016/S0959-6526(02)00111-7.

URL http://www.sciencedirect.com/science/article/pii/S0959652602001117

[18] S. Reddy, J. Painuly, Diffusion of renewable energy technologies-barriers and stakeholders' perspectives, Renewable Energy 29 (9) (2004) 1431 - 1447. doi:http://dx.doi.org/10.1016/j.renene.2003.12.003.

URL http://www.sciencedirect.com/science/article/pii/S0960148103003975

[19] Ministère de l'environnement et Office National pour l'environnement, Tableau de bord environnemental de madagascar, Tech. rep. (2010).

[20] Stocktak ing USAID, Consommation, approvisionnement et aménagement durable, Tech. rep. (2008).

[21] http://www.alamanga.fr, accessed September 2016 (2016).

[22] X. Wang, F. Fragano, M. Gehringer, T. Johnson, F. Lecaros, E. Lima, J. Lin, Drilling Down on Geothermal Potential: An Assessment for Central America - Report of the Energy Unit of the Latin America and Caribbean Region of the World Bank, Tech. rep. (2012).

[23] L. Andrianaivo, V. Ramasiarinoro, Geochemical Characteristics of Thermal Springs in Volcanic Areas of Antsirabe - Itasy, Madagascar: Preliminary Results, (2011) .

[24] G. Sarazin, G. Michard, Rakotonindrainy, L. Pastor, Geochemical study of the geothermal field of Antsirabe Madagascar, Geochemical Journal 20 (1986) 41-50.

[25] L. Andrianaivo, V. Ramasiarinoro, Geothermal Energy in Madagascar: Assessment Development Update, MadaHary 1 (2013) .

[26] Observ'ER and EDF and Fondation énergies pour le Monde, Fifteenth Inventory - Edition 2013, Worldwide electricity production from renewable energy sources, Chapter 3: Renewable origin electricity production : details by region and by country, Tech. rep. (2013).

[27] P. Chaperon, J. Danloux, L. Ferry, Fleuves et Rivières de Madagascar, (1993) .

[28] P. Ramarojaona, E. Andriamboavonjy, A. Elison, Madagascar face aux defis du changement climatique,

[29] United Nations Industrial Development Organization (UNIDO) and International Center on Small Hydro Power (ICSHP), World small hydropower development report 2013, Tech. rep. (2013).

[30] V. Beguerie, K. Blanchard, The potential for renewable energies in rural areas of madagascar, Tech. rep. (2009).

[31] Common Market for Eastern and Southern Africa (COMESA), Baseline renewable energy database for the comesa region, Tech. rep. (2012).

[32] E. J. Newjec inc, Preliminary study for expansion of manandona hydroelectric power plant in madagascar, Tech. rep. (2009).

[33] M. Randrianarisoa, Energies durables pour tous : les ménages, les collectivités et les entreprises, Tech. rep. (2013).

[34] ADER and GRET Madagascar, Rhyviere madagascar - réseaux hydroélectriques villageois : Energie et respect de l'environnement, Tech. rep. (2008).

[35] F. Bertholet, V. Rakotondramanana, Le secteur electrique : Un potentiel de developpement qui reste à exploiter, 
(2010) .

[36] United Nations Environment Programme (UNEP), Financing renewable energy in developing countries, Tech. rep. (2012).

[37] L. Hammar, J. Ehnberg, A. Mavume, B. C. Cuamba, S. Molander, Renewable ocean energy in the western indian ocean 16 (7) (2012) 4938-4950. doi:10.1016/j.rser.2012.04.026.

URL http://www.sciencedirect.com/science/article/pii/S1364032112003012

[38] A. Journoud, F. Sinama, F. Lucas, Experimental ocean thermal energy conversion (OTEC) project on the reunion island, 2012 , p. 8.

[39] M. Martins, F. Sinama, F. Lucas, Equivalent gibbs systems for modelling an onshore OTEC experimental plant on reunion island 37 (9) (2013) 1112-1121. doi:10.1002/er.2911.

URL http://dx.doi.org/10.1002/er.2911

[40] H. Jung, J. Hwang, Feasibility study of a combined ocean thermal energy conversion method in south korea 75 (0) (2014) 443-452. doi:10.1016/j.energy.2014.07.096.

URL http://www.sciencedirect.com/science/article/pii/S0360544214009360

[41] F. Sun, Y. Ikegami, B. Jia, H. Arima, Optimization design and exergy analysis of organic rankine cycle in ocean thermal energy conversion 35 (0) (2012) 38-46. doi:10.1016/j.apor.2011.12.006.

URL http://www.sciencedirect.com/science/article/pii/s0141118712000028

[42] L. A. Vega, D. Michaelis, First generation 50 MW OTEC plantship for the production of electricity and desalinated water, 2010, p. 17.

715 [43] J. Khan, G. S. Bhuyan, Ocean Energy : Global Technology Development Status (2009).

[44] R. Henderson, Design, simulation, and testing of a novel hydraulic power take-off system for the pelamis wave energy converter 31 (2) (2006) 271-283. doi:10.1016/j.renene.2005.08.021.

URL http://www.sciencedirect.com/science/article/pii/S0960148105002259

[45] D. Prandle, Simple theory for designing tidal power schemes 7 (1) (1984) 21-27. doi:10.1016/0309-1708(84)900265 .

URL http://www.sciencedirect.com/science/article/pii/0309170884900265

[46] T. J. Hammons, Tidal power 81 (3) (1993) 419-433. doi:10.1109/5.241486.

[47] C. Magori, Tidal Analysis and Prediction in the Western Indian Ocean (2008).

URL http://sealevel.odinafrica.org/reports/regional_wio.pdf

[48] H. Vetter, Solar cooker projet of ADES, Madagascar Conservation \& Development 1 (1) (2006) 22-24. doi:http://dx.doi.org/10.4314/mcd.v1i1.44034.

[49] Solargis (Accessed June 2016).

URL http://solargis.info/doc/_pics/freemaps/1000px/ghi/SolarGIS-Solar-map-Madagascar-en.png

[50] Fondem, accessed August 2016 (2016). [link].

URL http://www. fondem.ong/carte-actions-fondation/

[51] Agence de l'Environnement et de la Maitrise de l'Energie (ADEME), Atlas climatique de madagascar, Tech. rep. (2003).

[52] ADER, Madagascar wind atlas, Tech. rep. (2012). 
[53] A. Liebard, R. Ramanantsoa, De l'électricité verte pour un million de ruraux a Madagascar. Fondation energies pour le monde, Tech. rep.

[54] Ministry of Energy and Mines, WWF, Diagnostic du secteur énergie à Madagascar, Tech. rep. (2012).

[55] Jiro sy Rano Malagasy (JIRAMA), Installation performance of JIRAMA summary (Power plants and generating set)- juin 2012, Tech. rep. (2012).

[56] A. M. T. Randrianarisoa, Energies durables pour tous : les ménages, les collectivités et les entreprises, Tech. rep. (2013).

[57] Jiro sy Rano Malagasy (JIRAMA), Evolution annuelle des productions, ventes et nombre d'abonnes 1987-2011, Tech. rep. (2011).

[58] Institut National de la Statistique (INSTAT), Enquête périodique auprès des ménages (2010), Tech. rep. (2011).

[59] International Energy Agency, World Energy Outlook 2013 - Electricity database (2013, accessed December 15, 2016).

URL http://www . worldenergyoutlook.org/media/weowebsite/energydevelopment/WE02013Electricitydatabase.xlsx

[60] United Nations - Department of Economic and Social Affairs- Population Division, World Population Prospects: The 2012 Revision, CD-ROM Edition. (2013).

[61] K. Treyer, C. Bauer, Life cycle inventories of electricity generation and power supply in version 3 of the ecoinvent database - part i: electricity generation, Int J Life Cycle Assessdoi:10.1007/s11367-013-0665-2.

URL http://dx.doi.org/10.1007/s11367-013-0665-2

[62] U.S Energy Information Administration, Overview data for Madagascar (2013).

[63] Öko Institut, Global Emissions Model of Integrated Systems (GEMIS), version 4.8, no. August, 2008.

[64] A. Voninirina, S. Andriambelosoa, Etude sur L'Energie à Madagascar, (2014) . 